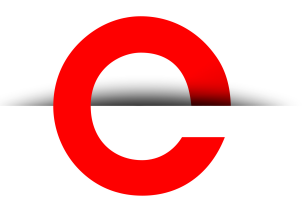

U T S

e PRES S
PORTAL Journal of Multidisciplinary International Studies

Vol. 17, No. $1 / 2$

Jan 2021

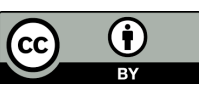

(C) 2021 by the author(s). This is an Open Access article distributed under the terms of the Creative Commons Attribution 4.0 International (CC BY 4.0) License (https:// creativecommons.org/ licenses/by/4.0/), allowing third parties to copy and redistribute the material in any medium or format and to remix, transform, and build upon the material for any purpose, even commercially, provided the original work is properly cited and states its license.

Citation: Camellia, S., and Fattah, K. N. 2021 Torn between Two Worlds: Unsettled Sense of Place and Belongingness between Old and New Homelands during a Global Pandemic. PORTAL Journal of Multidisciplinary International Studies, 17:1/2, 62-66. http://dx.doi. org/10.5130/pjmis.v17i1$\underline{2.7418}$

ISSN 1449-2490 | Published by UTS ePRESS I http://epress. lib.uts.edu.au/ojs/index.php/ portal
ESSAY

\section{Torn between Two Worlds: Unsettled Sense of Place and Belongingness between Old and New Homelands during a Global Pandemic}

\author{
Suborna Camellia ${ }^{1}$ and Kazi Nazrul Fattah ${ }^{2}$ \\ ${ }^{1}$ Radboud University \\ ${ }^{2}$ University of Melbourne
}

Corresponding author: Suborna Camellia, Doctoral Candidate, Gender \& Diversity Studies, Radboud University, Houtlaan 4, 6525 XZ Nijmegen, Netherlands. s.camelliadgamail.com

DOI: http://dx.doi.org/10.5130/pjmis.v17i1-2.7418

Article History: Received 11/09/2020; Accepted 11/11/2020; Published 28/01/2021

\begin{abstract}
The COVID-19 pandemic has impacted migrants physically, emotionally, economically and socially in both the global North and South. Emerging scholarship argues that to understand the dis-equalising impacts of COVID-19 on migrants it is necessary to consider their specific social situations across diverse contexts. In this essay we reflect critically on our experiences as first-generation aspirational immigrants in Australia and explore how the pandemic has unsettled our senses of place and belongingness in both our old and new homelands (Bangladesh and Australia). The closing of borders during the COVID-19 pandemic has underlined that immigrants experience unique vulnerabilities as they struggle with the burden of belonging in two different worlds.
\end{abstract}

\section{Keywords}

COVID-19; Belongingness; Immigrants; Vulnerabilities; Social Inequality

\section{Introduction}

In June 2020, Andrew Dawson, Professor of Anthropology at the University of Melbourne, wrote that the experience of living in Australia during the COVID-19 pandemic has strengthened his sense of belonging to his adopted country (2020). Reflecting on Australia's successful handling of the crisis compared to his home country the United Kingdom, he 
U T S

e PRES S

explained that the Australian way of dealing with the pandemic made him feel 'more Australian' and strengthened his sense of national identity. Our personal experience has little resonance with Dawson's. As recent immigrants to Australia from Bangladesh, we had hoped to develop a sense of belongingness to Australian society. Our endeavour to create a better future in Australia was interrupted by our caring responsibilities in Bangladesh, a country that has largely failed to ensure care for elderly people during the pandemic and the shrinking Australian labour market. In this paper we reflect critically on our experience of living through the pandemic and argue that unlike Professor Dawson whose social context allows him to deepen his ties to his adopted homeland, the pandemic in our case has unsettled our sense of place and belongingness in both our old and new homelands.

\section{From Bangladesh to Australia: Escaping the Past for a Better Future}

We are among the group of people often called 'diaspora' or 'transnational' in academic literature, and 'skilled migrants' in Australian immigration policies. We, however, prefer to view ourselves as aspirational Bangladeshi immigrants. We have material aspirations, such as securing a stable career in academia and owning a small but beautiful apartment/house somewhere in Australia. We also aspire to live in an equal, fair society. In Bangladesh we both had well established careers in our respective fields and could afford a fairly decent middle-class life. There were no economic reasons for us to migrate to Australia. We chose to leave behind our life of convenience in Dhaka to escape a deep frustration and anxiety with the widespread corruption and injustice in almost every sector in Bangladesh and the increasing normalisation of intolerance towards people who share alternative views about religion or politics. Being part of the higher educated middle-class in Bangladesh we had the 'capacity to aspire' (Appadurai 2004) for a better future and the ability to migrate to a fairer and just society.

Yet, we could not escape our past in Bangladesh as we had to leave behind our elderly parents who need care. Several years after migrating to Australia, we are still managing the care responsibilities for our parents in Dhaka while also completing our PhDs. Aged care in Bangladesh is largely neglected in existing healthcare policies. The absence of formalised aged care services leaves adult children responsible for their elderly parents' health and wellbeing. Prior to leaving Bangladesh, we had managed to set up an informal care system for our parents with support from friends and relatives. Even in a developing country like Bangladesh, managing care responsibilities from another continent became possible due to internet and mobile technologies and a small number of caring friends and relatives. However, once the pandemic hit Bangladesh the informal care system that we had set up for our parents ceased to function due to continued lockdown and mobility restrictions. The feeling of frustration and anxiety that we were so eager to escape from intensified. Despite physically being in Australia, in our minds we remain in Bangladesh, perhaps more so than ever. By putting people we love and care for in an extremely vulnerable position, COVID-19 has in effect unsettled our sense of belongingness in Australia. It led us to question the ways we relate to our old and new homelands.

\section{COVID-19 in Bangladesh}

The first three COVID-19 cases were reported in Bangladesh on March 8 and as of November 5, the total reported cases according to government sources, are 412,647 with 5,983 deaths (Directorate General of Health Services 2020). Because of the Government's 'not-so-secret' policy of suppressing reporting on COVID-19 cases, many believe that these numbers are the tip of the iceberg (Cousins 2020). While elderly people everywhere are particularly vulnerable to COVID-19, in Bangladesh this vulnerability is multiplied due to their dependence on others for basic needs. This has been exacerbated because of extended periods of lockdown and huge social stigma surrounding the disease. There have been reports in national media of ailing elderly parents being abandoned by their sons and daughters upon suspicion that their parents 
contracted the disease ('Mother with COVID-19 Symptoms' 2020). In some cases, patients are turned away at hospital doors if they have COVID-19 symptoms (Chowdhury 2020). There are numerous incidents of contradictory test results, leaving people in doubt about the quality of the testing procedure (Bappa 2020).

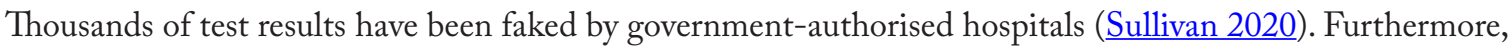
corruption and theft during procurement of medical supplies and equipment government agencies has made the situation worse (Balland 2020).

Against this backdrop, every day has become a struggle for us to cope with an overwhelming feeling of stress and anxiety. At the beginning, those getting infected were unfamiliar-positive cases were represented by numbers and statistics—distant and nameless. Gradually, it came closer and closer, the numbers suddenly morphing into the names and faces of close friends, relatives, neighbours and former co-workers. We knew that the consolidated number of deaths reported by the media each day contained many of those names and faces. Since then, we wake up every morning apprehensive of receiving bad news and at night go to bed with constant fear of losing dear ones in Bangladesh. What would we do if our parents fall ill? That is the fear we are living every moment. We have been standing on the verge of giving up on our dream of living a better life in Australia. As much as we would like to be there for our parents, we are scared to go back to that unjust world which we worked very hard to leave behind.

\section{COVID-19 in Our New Home Australia}

Australia is one of the few countries that has been dealing with COVID-19 successfully and as of November 2020 has suffered far less deaths from the pandemic compared to many other similar countries. In the quiet, leafy suburb in Queensland where we live there seems to be little sign of an ongoing pandemic aside from the now almost ubiquitous notices advising people to maintain physical distancing. Yet, living in one of the safest places in the world does not make us feel safe while our other home has become one of the world's most dangerous hotspots of the virus. The contrast we live between our two homes is bizarre and painful. Our feeling of insecurity heightens with the current travel ban on Australian residents. Soon after the global outbreak of COVID-19, we decided to leave Australia to be with our parents. However, as we were preparing to relocate to Dhaka, the Government issued an international travel ban for all Australian residents that barred us from leaving the country. Not being able to support our parents in these difficult times takes a huge toll on our emotional wellbeing. Our permanent resident status in Australia has put us in a vulnerable situation.

The shutdown of the job market in Australia has worsened the situation by significantly increasing the feeling of uncertainty and insecurity. The shutdown of businesses led to the first economic recession in 30 years and nearly one million Australians have lost their jobs since the onset of the pandemic (Janda 2020). It is highly unlikely that this situation will improve in the near future. We are about to complete our $\mathrm{PhDs}$ and had been looking forward to starting an academic career. That now seems a distant reality. We came to Australia because we wanted to contribute. We do not want to receive the government JobSeeker payment to survive. For us, developing a strong sense of belongingness and becoming Australian lies in the contribution we want to make to Australian society.

Our sense of belongingness to Australia has been further unsettled by the racial abuse against Asian and Indian immigrants (Zhou 2020; Grewal 2020). The common racist remark 'Go back to your $\mathrm{f}^{* * *}$ ing country' shouted from fast moving cars as they pass by, questions our very existence in a society where we look forward to contributing and belong. The constant feeling of insecurity which we wanted to leave behind in our old homeland in Bangladesh has now become part of our everyday life in Australia. COVID-19 has made us relive our past insecurities. The past has become very immediate as we worry about our parents there and our future here. 
U T S

e PRES S
Our dreams of building a better home in Australia has drifted further as we move deeper into a state of uncertainty of place and belongingness. We feel torn between two worlds, between past and future and between two homes. We remain suspended in an in-between space, neither fully belonging here nor there. Should we return to the insecure world we left behind in Bangladesh? Or should we continue to endure the uncertainties in Australia, despite the huge toll on our mental health and productivity, to see what the future may hold for us here? That is the question that defines our everyday life during the pandemic.

\section{Conclusion}

The everyday experiences of living through a global pandemic has very dissimilar social, economic, and emotional impacts on immigrants. For us, the anxieties of losing loved ones in Bangladesh to COVID-19, combined with the growing insecurities of making a foothold in the shrinking Australia labour market, have become part of our everyday lives. COVID-19 is a symptom of a much larger, albeit hidden, problem. Our marginalisation cannot be understood simply as an impact of COVID-19. It gets shaped at the intersection of multiple and multi-dimensional axes of social inequalities that needs to be investigated, questioned and dismantled. Our story explains why we are unable to feel 'more Australian' like Professor Dawson. For us immigrants from the Global South, the dream of belonging remains an elusive proposition.

\section{References}

Appadurai, A. 2004, 'The Capacity to Aspire: Culture and the Terms of Recognition' in Culture and Public Action, (eds) V. Rao \& M. Walton, Stanford University Press, Stanford, CA: 59-84.

Balland, S. C. 2020, 'Bangladesh and COVID-19: A Disaster within a Disaster,' Asia Times, 18 June. Online, available: https://asiatimes.com/2020/06/bangladesh-and-covid-19-disaster-within-a-disaster/ [Accessed 8 September 2020].

Bappa, A. T. 2020, 'DGHS Facing Criticism for Providing Contradictory Results,' The Finance Today, 28 July. Online, available: https://www.thefinancetoday.net/article/health/12878/DGHS-faces-criticism-for-providing-contradictorytest-results [Accessed 8 September 2020].

Chowdhury, T. 2020, 'COVID-19: Bangladesh Hospitals Forced to Turn Away Patients,' Al Jazeera, 7 April. Online, available: https://www.aljazeera.com/news/2020/04/covid-19-bangladesh-hospitals-forced-turnpatients-200407131633280.html [Accessed 8 September 2020].

Cousins, S. 2020, 'Bangladesh's COVID-19 Testing Criticised,' The Lancet, vol. 396, no. 10251: 591. https://doi. org/10.1016/S0140-6736(20)31819-5

Dawson, A. 2020, 'How COVID-19 Made Me More Australian,' Public Affairs, 19 June. Online, available: https:// pursuit.unimelb.edu.au/articles/how-covid-19-made-me-more-australian [Accessed 8 September 2020].

Directorate General of Health Services. 2020, Corona Info. Online, available: https://corona.gov.bd [Accessed 5 November 2020]

Grewal, P. 2020, "Go Back to Your F**king Country, You Brought Coronavirus Here”: Indian Student Racially Abused, Assaulted in Adelaide,' SBS Punjabi, 30 June. Online, available: https://www.sbs.com.au/language/english/audio/goback-to-your-f-king-country-you-brought-coronavirus-here-indian-student-racially-abused-assaulted-in-adelaide [Accessed 8 September 2020].

Janda, M. 2020, 'Almost a Million Australians Out of Work Due to Coronavirus; RBA Tips Economy to Take 10pc Hit,' $A B C$ News, 5 May. Online, available: https://www.abc.net.au/news/2020-05-05/almost-one-million-australianslose-jobs-due-to-coronavirus/12215494\#: :text=Almost $\% 201 \% 20$ million\%20Australians\%20have,a\%2010\%20per\%20 cent $\% 20$ hit [Accessed 8 September 2020]. 
'Mother with COVID-19 Symptoms "abandoned" in Sakhipur forest,' 2020, Prothom Alo, 14 April. Online, available: https://en.prothomalo.com/bangladesh/local-news/mother-with-covid-19-symptoms-abandoned-in-sakhipur-forest [Accessed 8 September 2020].

Sullivan, H. 2020, 'Global Report: Bangladesh Hospital Owner Accused of Faking Thousands of COVID-19 Test Results,' The Guardian, 16 July. Online, available: https://www.theguardian.com/world/2020/jul/16/global-reportbangladesh-hospital-owner-accused-of-faking-thousands-of-covid-19-test-results [Accessed 8 September 2020].

Zhou, N. 2020, 'Asian Australians Threatened and Spat on in Racist Incidents amid Coronavirus,' The Guardian, 24 July. Online, available: https://www.theguardian.com/australia-news/2020/jul/24/asian-australians-threatened-and-spat-onin-racist-incidents-amid-coronavirus [Accessed 8 September 2020]. 